\title{
Argobba and Amharic: Putting a Stop to a Quandary
}

\author{
Getahun Amare * \\ (Addis Ababa University, Ethiopia)
}

\begin{abstract}
This paper aims at producing and analyzing substantial linguistic data to point up differences between Argobba and Amharic. The paper argues against prior studies (Bender, 1976; Bender and Fulas, 1978; Zelealem, 1994; Leslau, 1997) which consider Argobba as a dialect of Amharic. There are also a few works which suggest that Argobba is an independent language of its own (Waldron, 1984; Wetter, 2006).These works, however, have not produced concrete linguistic evidence to substantiate their claim. This brings about the relation between Amharic and Argobba not to be comprehensible. This study, thus, intends to make this hazy issue to come to an end by providing comparable grammatical facts from both languages. The paper also provides counter examples which challenge the claims in Hudson (1997). The paper presents concrete linguistic facts that clearly show that Argobba and Amharic are not dialects of one another, but independent sister languages. It is strongly believed that this will finish off the problem about the relation between the two languages and brings the full picture of Argobba as an independent language in Ethio-Semitic subfamily.
\end{abstract}

Keywords: Argobba, Ethio-Semitic, comparative, morpho-syntax, root, cognate, endangered

\section{Introduction}

According to the classification of Ethio- Semitic languages, Argobba and Amharic belong to the South Ethio-Semitic subfamily together with Harari and Gurage languages. According to Hetzron (1972), Argobba and Amharic belongs to the North Transversal subgroup within the South Ethio-Semitic subfamily.

Amharic is one of the most widely spoken languages in Ethiopia. According to Hudson (1997:457) it is the second most widely spoken Semitic language next to Arabic. It served as a national language for many decades. Currently, the language is used as an official

\footnotetext{
* Getahun Amare: Associate professor of Linguistics, Department of Amharic Language Literature and Folklore, Addis Ababa University, Ethiopia. E-mail: getahun.amare@aau.edu.et. He has published articles in reputable journals such as Journal of African Languages and Cultures (UK), Journal of Ethiopian Studies (Ethiopia), Ethiopian Journal of Languages and Literature (Ethiopia), Nordic Journal of African Studies (Finland). He has authored three books: English-Amharic Idioms Dictionary, Simplified Modern Amharic Grammar and Amharic Grammar for Elementary Schools.
} 


\section{Getahun Amare}

language of the Federal Government of Ethiopia and working language in Amhara, the Southern Nations, Nationalities and Peoples and Benishangul Gumuz regional states. It is used as a lingua-franca in many cities and regional states. From its historical prestige and wider distribution in the country, one can predict its influence on minority languages like Argobba.

The Argobba language is used by the Argobba people living in some Argobba villages. As the Argobba people live within close proximity and close social and economic interaction with different ethnic groups in different regional states, they are bilinguals mostly in Amharic and/ or Afaan Oromo. The Argobba people living in Gacheni, Alyu Amba and Ankober, for instance, have by and large shifted to Amharic. Likewise, the South Argobba, in Harar, has given way to Afaan Oromo. As it has been learned from three field trips to different Argobba areas, the only places where there are fluent Argobba speakers are Shonke and Telha, which are found in Kemissie Zone of the Oromiya Regional State in Amhara Regional State. It is only in these places we find young speakers of the language.

Researchers identify Argobba with different level of endangerment. For instance, Battibo (2005:147) identifies it as extinct or nearly extinct language together with other Ethiopian languages like Ge'ez, Gafat etc. According to Gabriel (1992:309), Argobba is in the process of extinction. For Leslau (1997: xv), it is a dying language and if not dead in some regions.

With regard to its status, some scholars consider Argobba as a dialect of Amharic. Bender and Fulas (1978:5), for instance, write, "Amharic does have one quite divergent dialect: Argobba. This is probably best considered as a "Muslim dialect." Correspondingly, Zelealem (1994:13) says, "I suggest that Argobba and Amharic are dialects of one another, not independent languages." Leslau (1978:2), in his part, tries to assert that Argobba is the dated form of Amharic by saying “... while Argobba has certain features found in one or another South Ethiopian language, it is the most closely related to Amharic. It seems even safe to say that Argobba presents an older stage of Amharic." The same author in his book entitled 'Ethiopic Document: Argobba Grammar and Dictionary' concludes by writing "The mutual intelligibility combined with many common features between Amharic and Argobba leads me to the conclusion that Argobba is an Amharic dialect." (Leslau 1997:131).

Contrary to these assumptions forwarded by the above mentioned scholars, a few researchers argue that Argobba is an independent language. Waldron (1984:50) claims that although Argobba is closely related to Amharic, it is a distinct language. Correspondingly Wetter (2006), in his preliminary overview of the T'ollaha variety of Argobba, claims that Argobba is an independent language. Neither of them provides sufficient linguistic data to substantiate their claim. Particularly, Waldron (1984) has not produced linguistic evidence 
that substantiates the proposed contention. That is why the status of Argobba has stayed behind so long distorted.

The issues raised so far enlighten that the status of Argobba or the relation between Amharic and Argobba is not clear. This study, thus, provides tangible linguistic evidences to put an end to the dilemma.

To this effect, the study argues against the works by Bender (1976), Bender and Hilu Fulas (1978) and Zelealem (1994), and Leslau (1997) which consider Argobba as a dialect of Amharic; and take side with the studies by Wetter (2006), which mainly focuses on the T'ollaha variety, and Waldron (1984). In Waldron's study, we do not find linguistic evidence that validates the proposed argument. This study, however, provides a comparative analysis between Argobba and Amharic ranging from phonology to syntax. So as to make the study comprehensive, unlike the case in Wetter (2006), the data from Argobba is not limited to only one variety. It is, therefore, claimed in this paper that Argobba is an independent language sister to Amharic. The study also goes against linguistic examples which were provided in Hudson (1997). In this study, counter examples from Argobba are offered to show the flaws of the data used in Hudson (1997).

The paper has five major sections. In section 2, previous studies on Argobba are reviewed. In section 3, the phonology of the two languages will be discussed contrastively. Section 4 makes a comparative analysis of the morphosyntactic structures of the two languages. Finally, section 5 summarizes the discussion and puts forward concluding remarks.

\section{Previous studies on Argobba}

Based on their principal focuses, previous studies conducted on the Argobba language could be categorized mainly on classification, vocabulary, comparison, description, sociolinguistic survey, orthography and dictionary. The works in each of these categories will be addressed as follows.

The Argobba language belongs to the Ethio-Semitic language family under the Afro-Asiatic phylum. The Ethio-Semitic language family has two sub-families: North Ethio-Semitic and South Ethio-Semitic subfamilies (Leslau, 1966; Hetzron, 1972; Hudson, 2000). Argobba is belonging to the South Ethio-Semitic sub-family together with Amharic, Harari and the Gurage languages.

The first list of vocabularies, having the name Argobba, goes back to 1816 by Seetzen Ulric. Leslau (1949), however, attests that the words were Silti-Wolane, not Argobba. In 1845, Lefebvre also has provided lists of vocabularies. Cohen (1931) incorporates the earlier Argobba vocabularies and has lists of some nouns and numerals 1-10 with their equivalents in German. In 1939, Cohen also has a similar work mainly on the vocabulary 


\section{Getahun Amare}

of South Argobba. Leslau (1978) lists vocabularies collected from Ankober and Addis Ababa. Leslau (1960) tries to indicate the position of Argobba within the classification of Ethio-Semitic languages comparing some of Argobba grammatical features with other related languages.

Hetzron's (1972) work, which deals with Ethio-Semitic classification, has one subsection which discusses the comparison between Amharic and Argobba. He presumes that the two languages form a closer unit in the classification. Hudson (1997) has done a relatively recent comparative study between Argobba and Amharic. Hudson's study shows strong similarity between Amharic and Argobba. Wetter (2006) also has conducted a research on the T'ollaha Argobba variety.

The first descriptive work on the grammar of Argobba is Leslau's (1959) article. The next work that can be considered as a linguistic description is Zelealem's (1994) survey report. Zelealem briefly describes the phonology, morphology and syntax of the language. Leslau (1997) collected his articles from different sources and compiled them in his book 'Ethiopic Documents: Argobba Grammar and Dictionary'. Voigt (2003) has given short encyclopedic information about the Argobba language in the Encyclopedia Aethiopica. Voigt's description was mainly based on Leslau's 1997 and Zelealem's 1994 survey report.

Getahun has described the causative and the relative clause constructions in 2006 and 2008 respectively. In 2009, the same author has described and analyzed the verb morphology and syntax of the language based on Head-driven Phrase Structure Grammar (HPSG) framework. This study gives both descriptions and theoretical analysis. He has also described and analyzed the passive construction of the language in 2010. Wetter (2010) has described the grammar of Argobba based on the variety spoken in Shonke and T'ollaha in the German language.

Siebert (1994) conducted a sociolinguistic survey in Shewa Robit. He found out that the Argobba spoken in the area is highly influenced by Amharic. The survey has also discovered that although the Argobba speakers in Shewa Robit were descended from Shonke ten years back, it is hardly possible for them to understand the Shonke variety.

The other sociolinguistic survey carried out on Argobba was by Hussein et al. in 2006. Unlike the survey in 1994, this survey covered most of the Argobba areas and came up with detailed sociolinguistic information.

As far as the researcher's knowledge goes, two Argobba orthography development attempts have been made. The first attempt was made by Gebre in 1991. Gebre adopts the syllabic writing system as used in Amharic. The proposed orthography is based on the phonology of the Shonke variety without taking into consideration the other varieties of the language. The second attempt was made by Demeke in 2006. Demeke's work was based on the phonology of the Gacheni variety. The proposed orthography has been designed by 
adopting the Ethiopic writing system.

The first work to be considered as an Argobba bilingual dictionary (Argobba- Amharic) was made by Ahmed \& Meded (n.d). Although the book is organized as a bilingual


Teaching Material, not Argobba dictionary). In this book, the Argobba entries are written in Arabic and the Amharic translations (definitions) are written in Ethiopic script. The Argobbina-Amarina məzgəbə K'alat (Argobba -Amharic dictionary), compiled by Demeke in 2003, is a proper bilingual dictionary in both form and content.

\section{Phonology}

The voiceless pharyngeal fricative $/ \hbar /$, the voiceless pharyngeal stop $/ q /$ and the voiceless velar fricative / $\mathrm{x} /$, which exist phonemically in Argobba do not exist in Amharic. Furthermore, the voiceless glottal stop / $/$ /, which is almost lost in Amharic, and the voiceless glottal fricative / $h$ /, which is lost in many words in Amharic, have been retained in Argobba. The following cognate words from the two languages illustrate the loss of the sounds in question in Amharic.

$\begin{array}{lll}\text { (1) Gloss } & \text { Amharic } & \text { Argobba } \\ \text { hit } & \text { mətta } & \text { məttə? } \\ \text { finger } & \text { t'at } & \text { t'a?ut } \\ \text { tie } & \text { assərə } & \text { Passər } \\ \text { forty } & \text { arba } & \text { harba } \\ \text { lick } & \text { lasə } & \text { ləhas }\end{array}$

On the other hand, the voiceless bilabial stop /p/ and the voiceless bilabial ejective / $\mathrm{p} /$ as well as the alveolar ejective /s'/ which are found in Amharic are absent in Argobba.

The voiceless stop /t/ in Amharic corresponds with the voiced stop /d/ at word final position, especially in the Argobba variety spoken in Gacheni and Alyu Amba as presented in (2).

\begin{tabular}{|c|c|c|}
\hline$\underline{\text { Gloss }}$ & Amharic & Argobba \\
\hline house & bet & bed \\
\hline death & mot & $\bmod$ \\
\hline face & fit & fìd \\
\hline
\end{tabular}

The bilabial stop /b/ in Amharic words corresponds with the bilabial semi-vowel /w/ in Argobba as shown in (3).

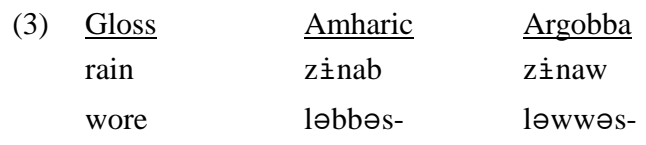




\section{Getahun Amare}

barley gəbs gəws

In Amharic, the alveolar sounds, except $/ \mathrm{r} /$, are palatalized in the stem final position occurring before the agentive morpheme $-i$. In Argobba, the palatalization is not commonly observed in the environment in question as indicated in (4).

$\begin{array}{lll}\text { (4) Gloss } & \text { Amharic } & \text { Argobba } \\ \text { killer } & \text { gədal-i [gəday ] } & \text { gədal-i [gədali] } \\ \text { farmer } & \text { aras-i [araš } & \text { haras-i [ harasi] }\end{array}$

In both Amharic and Argobba, there are seven vowel phonemes. In Amharic, the mid central vowel /ə/ does not occur word initially, but it occurs word medially and finally. On the contrary, in Argobba, the vowel occurs word initially and medially, but not finally.

In Amharic, the vowel sequence with /ə/ and / $/$ / results in the elision of /ì/. In Argobba, however, the sequence yields the high front vowel /i/. Consider the examples in (5) from both languages.

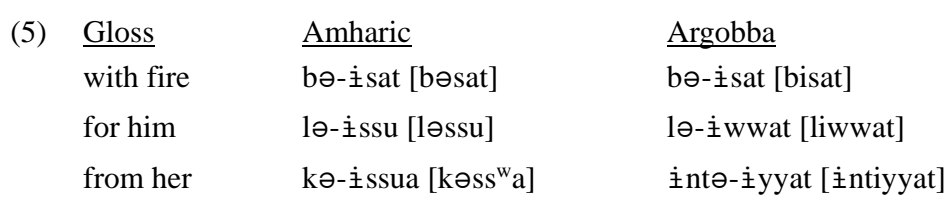

\section{Morpho-syntax}

In this section, we consider the morphological as well as the syntactic properties of nouns, pronouns, adjectives, verbs and adpositions in both languages.

\subsection{Nouns and pronouns}

\subsubsection{Nouns}

Because of the fact that Amharic and Argobba are sister languages, we find cognate nouns with minor phonological differences. Nevertheless, as independent languages, Amharic and Argobba have different primitive and derived nouns for the same meaning as shown in (6) and (7) respectively.

\begin{tabular}{|c|c|c|c|}
\hline \multirow[t]{6}{*}{ (6) } & $\underline{\text { Gloss }}$ & $\underline{\text { Amharic }}$ & Argobba \\
\hline & road & məngəd & ћema \\
\hline & sheep & bəg & hara \\
\hline & goat & fìyyəl & t'a?i \\
\hline & honey & mar & dus \\
\hline & tongue & mìlas & arrat \\
\hline \multirow[t]{4}{*}{ (7) } & $\underline{\text { Gloss }}$ & Amharic & Argobba \\
\hline & begging & li̇mməna & zurəta \\
\hline & wound & k’usìl & $t^{\prime} \dot{i} 1 \dot{x} ?$ \\
\hline & lending & wìsət & ћ主dgo \\
\hline
\end{tabular}


Argobba and Amharic: Putting a Stop to a Quandary

work sìra gə?ar

In both languages, nouns inflect for number and definiteness. Amharic and Argobba use the plural marker -očč and -ačč respectively. In Amharic, if the base noun ends in a vowel, the /o/ in -očc will not be affected. That is, either the vowel on the base noun is elided or the semi-vowel /w/ is inserted between the vowels as an epenthetic element. Thus, bəre 'ox' has the plural form bəročč or bərewočč. In Argobba, however, the /a/ in -ačč is consistently deleted when the noun ends in a vowel. Consequently, the nouns t'aPi 'goat', xənabo 'kid' and tatte 'mother' have the plural form t'aPičč, xənabočč and tattečc respectively. Amharic has some plural markers retained from Ge'ez, such as -at and -an like in k'al-at 'words' and nis s'uh-an 'righteous, pious', but these are absent in Argobba.

Both languages use gender marked definite suffixes. Amharic uses $-u$ and $-w a$ to denote definite masculine and feminine nouns respectively. In Argobba, however, the morpheme - $\check{c} \check{c} i$ and $-\dot{t} t i$ are used for masculine and feminine respectively. In Amharic, definite plural nouns are marked by $-u$. In Argobba, in contrast, plural nouns are not marked for definiteness. As a result, while the Amharic definite plural noun set-očč- $u$ 'the women' is formed with the plural morpheme and the definite article suffix, the comparable form in Argobba is expressed simply by $n \dot{i} \check{s} \check{c}$-ačc with the plural marker only.

In connection with this, in Amharic, if the definite noun is modified by an adjective or a quantifier, the definite article will move to the respective modifier or quantifier and surfaces suffixed to the respective qualifier. On the contrary, in Argobba, the definite suffix appears on the head noun, not on any qualifier. Consider the following examples.

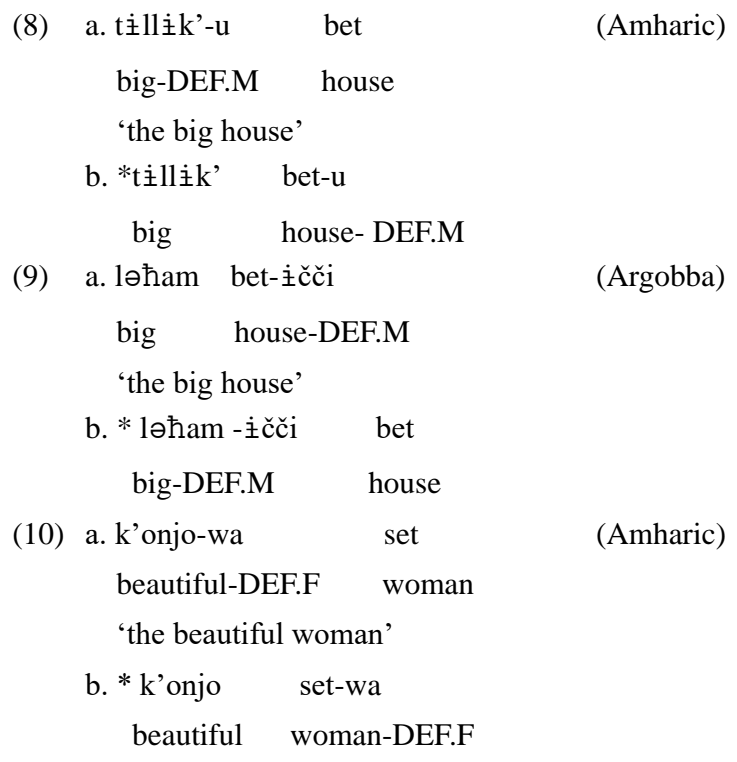




\section{Getahun Amare}

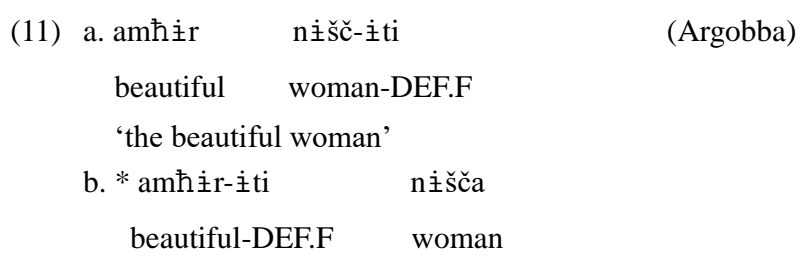

Accordingly, if a definite noun preceded by a modifier or a quantifier is used as an object of a transitive verb, the object case marker $-n$ appears on the modifier or quantifier together with the definite suffix in Amharic. In Argobba, however, the object case morpheme appears on the head noun. Consider the examples from both languages in (12).

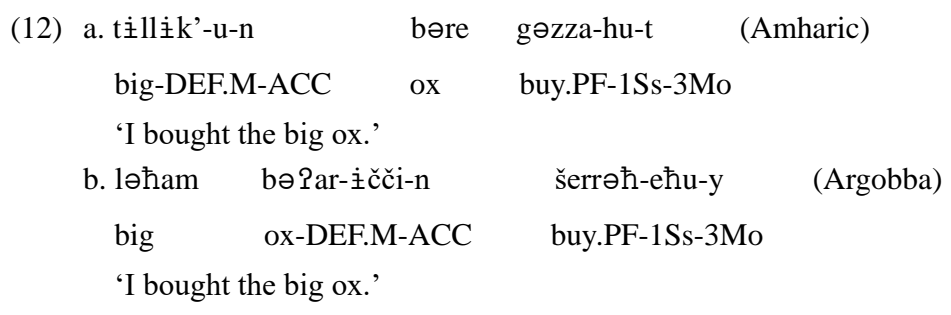

\subsubsection{Personal pronouns}

Both Amharic and Argobba have independent and dependent personal pronouns. We shall see the independent personal pronouns first and pass to the dependent ones in the immediately following subsection.

A. Independent pronouns

The following are independent personal pronouns in both Amharic and Argobba which can be used as a subject.

(13)

\begin{tabular}{|c|c|c|c|}
\hline \multirow{3}{*}{ sg. } & & Amharic & Argobba \\
\hline & 1 & ine & an/əy \\
\hline & $2 \mathrm{M}$ & antə & ank \\
\hline & $\mathrm{F}$ & anč(i) & anč/ aš \\
\hline & pol. & 主rswo & $\ldots$ \\
\hline & $3 \mathrm{M}$ & 主ssu & 主wwat/k主ssu \\
\hline & $\mathrm{F}$ & $\dot{\mathrm{i}} \mathrm{ss}^{\mathrm{w}} \mathrm{a}$ & 主yyat/ kìssa \\
\hline & pol. & 主ssaččəw & 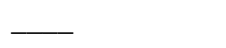 \\
\hline pl. & 1 &  & 主nna \\
\hline & 2 & 主nnantə & ankum/ìnnakum \\
\hline & 3 & 主nnəssu & 主1ləm/ k̇ \\
\hline
\end{tabular}

As it is observable from the list in (13), the polite pronoun forms are absent in Argobba. With regard to the rest of the pronouns, the two languages have similar as well as completely different pronoun forms. The first person singular an / $ə y$ and the third person íwwat 'he' iyyat 'she' and $\dot{\text { i } l l ə m}$ 'they' are completely different from the ones found in 
Amharic. The pronouns ki̇ssu 'he' and ki̇ssa 'she' are used in Gacheni, Alyu Amba and surrounding areas, however, these pronouns seem to be cognates with the corresponding Amharic pronouns (Leslau, 1997).

In Amharic, it seems that the plural independent personal pronouns are marked by the plural prefix i $n n \ominus-$ which is not the case in Argobba. Based on the facts we have at hand, it seems hardly possible to share Hudson's claim which reads "In Argobba, independent pronouns with the basis kəss- perhaps are derived from reflexive-emphatic pronouns consisting of the noun kärs 'belly' with the possessive suffixes" (Hudson, 1997:461).

In Amharic, the independent forms in (13), can be used as possessive and object pronoun by affixing $y ə-$ and $-n$ respectively. This means that there is one independent form in the language. In Argobba, some of the possessive and the object pronouns are different from the subject pronouns as shown in (14).

\begin{tabular}{|c|c|c|c|c|}
\hline \multirow[t]{5}{*}{ (14) sg. } & 1 & $\frac{\text { Subject }}{\text { an/əy }}$ & $\frac{\text { Possessive }}{\text { iyyo }}$ & $\frac{\text { Object }}{\text { iyyon }}$ \\
\hline & $2 \mathrm{M}$ & ank & $\mathrm{ax}$ & axon \\
\hline & $\mathrm{F}$ & anč/ aš & aš & ašon \\
\hline & $3 \mathrm{M}$ & 主wwat/kìssu & iwwat & 主wwaton \\
\hline & $\mathrm{F}$ & 主yyat/kìssa & iyyat & ̇yyaton \\
\hline \multirow{3}{*}{ pl. } & 1 & ̇̇nna & inna & innan \\
\hline & 2 & ankum/ìnnakum & axum & axumin \\
\hline & 3 & 主lləm/ kìssəm & illəm & ̇̇lləm⿱亠n \\
\hline
\end{tabular}

B. Dependent pronouns

The dependent pronouns are attached to nouns and verbs. Those which attach to nouns are possessive pronoun suffixes whereas those which attach to verbs are subject and object pronoun affixes. In this subsection, we are concerned only with the possessive suffixes; the subject and the object pronoun affixes will be picked up in subsection 4.5.3. The following examples illustrate the possessive pronouns with the Amharic noun $l \dot{\text { i }} b s$ 'clothes' and the Argobba noun gə ?ar 'work'.

(15)

\begin{tabular}{|c|c|c|c|}
\hline \multirow{2}{*}{ sg. } & & $\underline{\text { Amharic }}$ & $\underline{\text { Argobba }}$ \\
\hline & 1 & li主bs-e & gə?ar-⿱亠䒑yyye \\
\hline & $2 \mathrm{M}$ & lizbs-ìh & gə?ar- $\hbar /-a h$ \\
\hline & $\mathrm{F}$ & lìbs-主 $\breve{s}$ & gə?ar-ih \\
\hline & pol. & lìbs-əwo & - \\
\hline & $3 \mathrm{M}$ & lìbs-u & gə?ar-u \\
\hline & $\mathrm{F}$ & li主bs-wa & gə?ar-a \\
\hline & pol. & lìbs-aččəw & \\
\hline
\end{tabular}




\section{Getahun Amare}

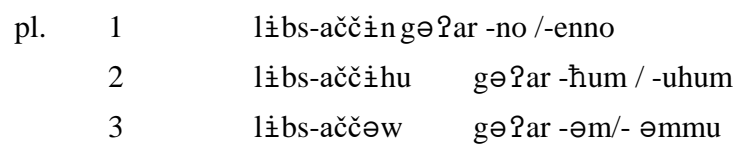

From the above illustrative examples, we become aware of the differences between the two languages, especially in the $2 \mathrm{~F}$ and the plural possessive suffixes.

Notice that in Amharic, but not in Argobba, the $3 \mathrm{M}$ and the $3 \mathrm{~F}$ possessive pronouns are homophonous with the definite article suffix $-u$ and $-w a$ that results in ambiguity in Amharic, such as $l \dot{i} b s-u$ can mean 'his clothes' or 'the clothes'.

In Amharic, reflexive is expressed by the noun ras 'head' and the possessive suffixes like ras-u 'himself', ras-ačč̇̇n 'ourselves' etc. In Argobba, the noun dimmah 'head' and $h \dot{i} m s$ 'soul' are used with the possessive suffixes mentioned above. For instance, the Amharic reflexive sentence in (16a) is expressed as in (16b) in Argobba.
(16) a. ras-aččəw-n
head-POSS.3PL-ACC
'They committed suicide.'
gəddəl-u
(Amharic)
b. hìms-əm-n
soul-POSS.3PL-ACC
gəddəl-əy
'They committed suicide.'
kill.PF-3PLs
(Argobba)

Reciprocal is expressed by $i$ irs bə-i $r s$ suffixing the plural possessive suffix in Amharic. In Argobba, reciprocity is expressed by reduplicating $h \dot{i} m s$ 'soul' and using a connecter $l i$ in between and suffixing the plural possessive suffix. Consider the examples in (17).
(17) a. ìrs bə-ìrs- (aččəw)
self by-self-PL
'They killed each other.'
tə-gaddəl-u
(Amharic)
RECP-kill.PF-3PLs
b. hìms li-hìms-(əm)
主ggadəl-əy
(Argobba)
soul for-soul-PL
RECP.kill.PF-3PLs
'They killed each other.'

\subsection{Interrogative and demonstrative pronouns}

Both languages have interrogative pronouns which consist of similar and different forms. Consider the following examples.

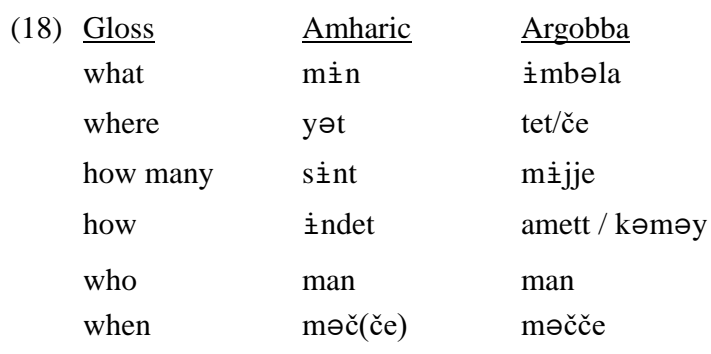


For the English equivalent interrogative pronoun 'why', both languages do not seem to use a lexical element, but a PP by combining the preposition $l \oslash$ - 'for' with the interrogative $m \dot{m} n$ and $\dot{i} m b \ominus l a$ 'what'. It, thus, surfaces as ləmi̇ $n$ in Amharic and limbəla in Argobba.

In Amharic, besides proximal and distal distinction, the demonstratives exhibit gender distinction. The same distinction is observed in one of the varieties of Argobba spoken in Gacheni and Alyu Amba. Based on the data from this variety, Hudson (1997:467) shows the demonstratives of the two languages in the following manner.

(19)

\begin{tabular}{|c|c|c|c|c|}
\hline \multirow{3}{*}{ Near } & \multirow[b]{2}{*}{$\mathrm{Sg}$. } & \multirow{2}{*}{\multicolumn{2}{|c|}{$\frac{\text { Amharic }}{\mathrm{yih}}$}} & \multirow{2}{*}{$\frac{\text { Argobba }}{\text { hud }}$} \\
\hline & & & & \\
\hline & & f. & 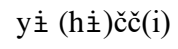 & huy \\
\hline \multirow[t]{2}{*}{ Far } & & $\mathrm{m}$. & ya & {$[\mathrm{o}:] \mathrm{d}$} \\
\hline & & f. & yačč(i) & [o:]y \\
\hline Near & & pl. & 主nnäzzih & hulläm \\
\hline Far & & pl. & 主nnäzzya & (w)[o:]11äm \\
\hline
\end{tabular}

In the Argobba variety spoken in Shonke and Telha, the demonstratives are marked for number, but not for gender as shown in (20) below.

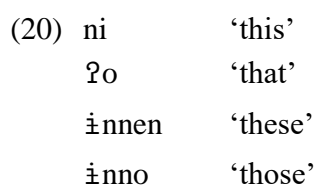

In this regard, Hudson's (1997:467) claim, based on the data in (19), that reads "Argobba plural forms appear to be cognate with Amharic hullu 'all' and the final $-m$ of these apparently cognate with Amharic," does not hold true for the data from Shonke and Telha.

The other interesting point worth mentioning is that in Argobba, but not in Amharic, a singular noun head modified by a demonstrative obligatorily bears the definite article suffix. Compare the examples from Amharic and Argobba (21) below.

\begin{tabular}{|c|c|c|c|c|}
\hline \multicolumn{3}{|c|}{ Amharic } & \multicolumn{2}{|c|}{ Argobba } \\
\hline \multirow[t]{2}{*}{ (21) } & a. ya & bəre & ?o & bəPar-主čči \\
\hline & that.M & ox & that & ox-DEF.M \\
\hline \multicolumn{3}{|c|}{ 'that ox' } & \multicolumn{2}{|c|}{ 'that ox' } \\
\hline & b. *ya & bəre-w & $*$ * & bə?ara \\
\hline & that.M & ox-DEF.M & that & ox \\
\hline & c. yi⿱一土čči & set & ni & $n \dot{n}$ šč- \\
\hline & this.F & woman & this & woman-DEF.F \\
\hline \multicolumn{3}{|c|}{ 'this woman' } & \multicolumn{2}{|c|}{ 'this woman' } \\
\hline & d. *y主čči & set-wa & $*_{\text {ni }}$ & nìšča \\
\hline & this.F & woman-DEF.F & this & woman \\
\hline
\end{tabular}




\section{Getahun Amare}

As can be observed from the examples in (21), a demonstrative and a definite suffix co-occur in a single NP in Argobba, but not in Amharic.

If a head noun specified by a demonstrative serves as a direct object, the object morpheme is attached to the demonstrative in Amharic, but on the head noun in Argobba. Consequently, the Amharic sentence in (22a) is expressed by the corresponding Argobba sentence in (22b).

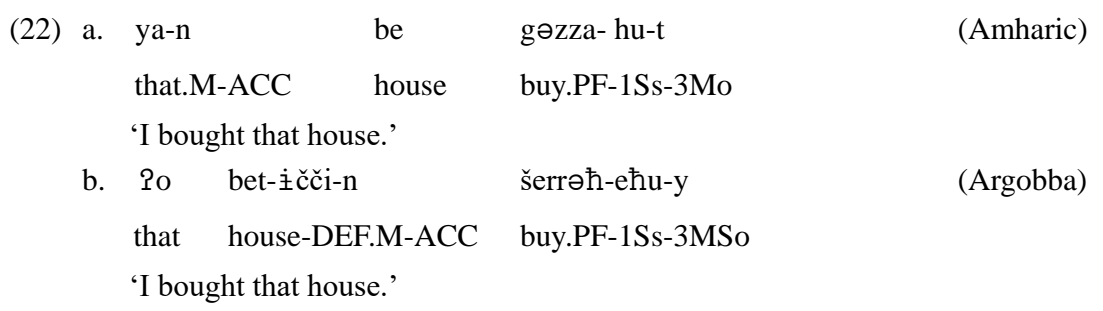

\subsection{Genitives}

In Amharic, genitive is expressed by the prefix yə- attached to a noun that precedes a head noun. The genitive prefix disappears when preceded by a preposition. While comparing Amharic and Argobba, Hudson (1997:465) says, "In Argobba the genitive prefix is yə-: yə-wədaj-iya 'of my friend', which also is absent if another prefix is present: bə-wədaj-iya fərəs 'on my friend's horse." What Hudson says is correct for Amharic, but not for Argobba. Firstly, contrary to Hudson's claim the genitive prefix is ə- not yə- in Argobba. Secondly, it disappears when another prefix precedes it because the language

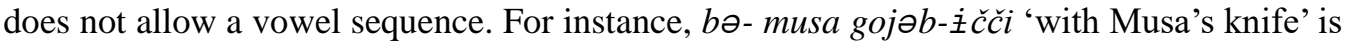
derived from bə-ə-musa gojəb-i̇ $\check{c} \check{c} i$. The obligatory attachment of the definite suffix to the noun head asserts that the structure is derived from the genitive NP. Hence, the structure bə- musa gojəb is unacceptable for the genitive meaning which is allowed in Amharic.

In connection with this, the significant difference between Amharic and Argobba is that like the case we discussed above with demonstratives, a singular head noun modified by a genitive NP, in Argobba, but not in Amharic, obligatorily bears the definite suffix. Consider the structures in (23).

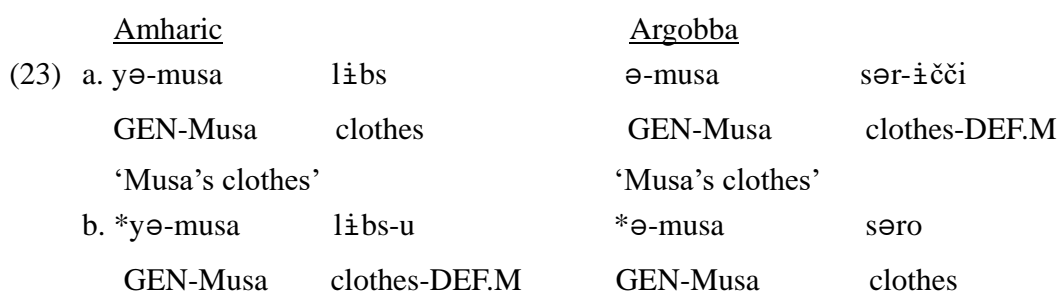

\subsection{Adjectives}

In both Amharic and Argobba, there is a category adjective which has attributive and 
predicative function. The majority of the adjectives are derived in both languages. There are, however, adjectives which are derived in Amharic, but primitive in Argobba. The following could be representative examples.

\begin{tabular}{|c|c|c|}
\hline (24) Gloss & Amharic & Argobba \\
\hline many & $\mathrm{b} \dot{\mathrm{z}} \mathrm{zu}$ & 主ndig \\
\hline strong & t'ənkarra & t'ek' \\
\hline small & 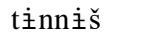 & 主ngilla \\
\hline wide & səffi & ruhi \\
\hline fat & wəfram & amud \\
\hline big & tì1lìk' & ləham \\
\hline
\end{tabular}

Consequently, the Amharic Adjectives in (24) have cognate verbal counterparts, but the ones in Argobba have not.

As sister languages, Amharic and Argobba have adjectives which are derived from the same root (proto forms) like fəri 'cowardly', sənəf 'lazy' etc. There are also adjectives which are derived from different roots, as seen in (25).

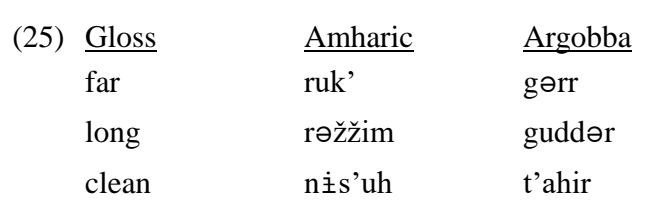

The adjectives in (25) from both languages have verbal counterparts derived from their respective roots. For instance, the adjective rəžžim in Amharic and the Argobba adjective $g u d d ə r$ are derived from the consonantal roots $r-z-m$ and $g-d-r$ respectively.

In both languages, substantive adjectives inflect for number. In Amharic, the plural adjectives are marked by -očč and reduplication. In Argobba, however, plural adjectives are marked by reduplication only. Hence, some adjectives, which are marked by the plural morpheme only in Amharic, are expressed by reduplication only in Argobba. The following data exemplifies the case in point.

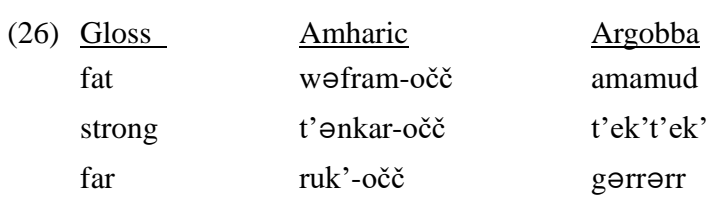

In Amharic, but not in Argobba, the plural adjectives in (26) obligatorily bear the definite article suffix. Hence, wəfram-očč- $u$ set- očc 'the big women' is acceptable, but wəfram-očč set-očc is not. In Argobba, however, neither the plural adjective nor the plural head noun bears the definite article. Thus, the Amharic NP, wəfram-očč- $u$ set-očc 'the big

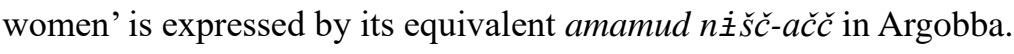




\section{Getahun Amare}

As presented in the preceding section, attributive adjectives in Amharic, take the definite suffix of the noun and as a result the noun will be left with its indefinite form. In Argobba, in contrast, the adjectives do not take the definite suffix of the noun, rather the definite suffix $-e$ and $-i t$ are used for masculine and feminine adjectives respectively. Consider the examples in (27) from both languages.

\begin{tabular}{|c|c|c|c|c|}
\hline \multicolumn{2}{|r|}{ Amharic } & \multicolumn{3}{|c|}{ Argobba } \\
\hline (27) & a. tìllk'-u & bəre & ləham-e & bəPar-主čči \\
\hline & big-DEF.M & ox & big-DEF.M & ox-DEF.M \\
\hline & 'the big ox' & & 'the big ox' & \\
\hline & b. wəfram-wa & set & amud-it & $n \dot{n}$ 汭č- $\dot{\text { it }} \mathrm{ti}$ \\
\hline & fat- DEF.F & woman & fat-DEF.F & woman-DEF.F \\
\hline & 'the fat woman & & 'the fat won & an' \\
\hline
\end{tabular}

From the examples in (26-27), we observe that in Amharic, irrespective of number, it is only the adjective that bears the definite suffix. In Argobba, in contrast a singular head noun modified by a definite adjective obligatorily bears the definite article suffix. Hence, both singular adjectives and head nouns bear their corresponding definite suffixes in Argobba, not in Amharic.

In connection with this, as indicated in 4.1.1, in Amharic, but not in Argobba, the accusative case suffix appears on the attributive adjective. In Argobba, the case morpheme appears on the head noun. As a result, the Amharic structure in (28a) is expressed as in (28b) in Argobba.

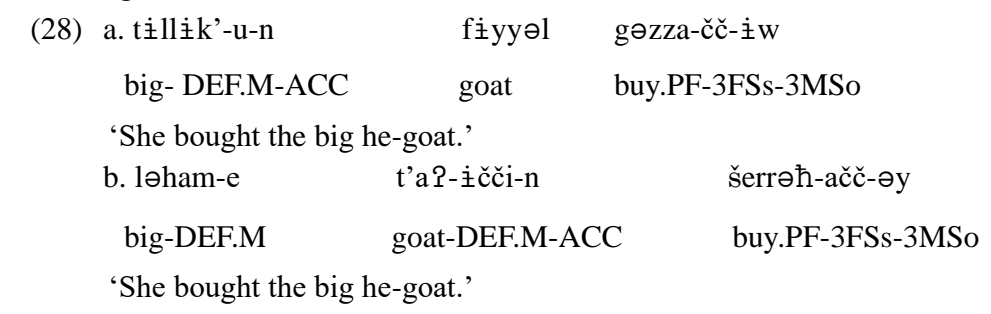

\subsection{Verbs}

\subsubsection{Root}

In both Amharic and Argobba, verbal stems are derived by inserting vowels between radicals in a consonantal root. The difference between the two languages is observed in the kind and number of consonant constituting surface stem forms. In cognate verbs, especially those with historic laryngeals, the Amharic ones have one less radical than the ones in Argobba. This is so because the consonants which have been lost in Amharic have been retained in Argobba. Consider the consonantal roots in the following surface verb stems. 


$\begin{array}{lll}\text { milk } & \text { alləb } & \text { halləw- } \\ \text { tie } & \text { assər } & \text { Passər- } \\ \text { be loose } & \text { lalla- } & \text { ləhalləh- } \\ \text { kiss } & \text { sam- } & \text { sə९am- } \\ \text { go } & \text { hed- } & \text { xəyd }\end{array}$

It is worthy to note here that although the examples in (29) show differences on the surface, Argobba and Amharic seem to have similar and equal number of root consonants at the underlying or abstract level.

\subsubsection{Derivation}

In addition to the difference mentioned in the preceding subsection, some verbs in both languages use different roots to derive their verbal stem for the same meaning.

\begin{tabular}{|c|c|c|c|c|}
\hline 0) Amharic & & & $\underline{\text { Argobb }}$ & \\
\hline Gloss & $\underline{\text { Root }}$ & $\underline{\text { Stem }}$ & $\underline{\text { Root }}$ & $\underline{\text { Stem }}$ \\
\hline drink & $t^{\prime}-t^{\prime}$ & t'ət't'a- & $\check{s}-\check{c}$ & šəčč- \\
\hline order & $\mathrm{z}-\mathrm{z}$ & azzəz- & P-m-r & Pemmər- \\
\hline stank & $\check{s}-\mathrm{t}-\mathrm{t}$ & šəttət- & š-n-č & šonč- \\
\hline get & $g-\check{n}$ & agəňň- & $\mathrm{r}-\mathrm{k}-\mathrm{w}$ & rəkkəw- \\
\hline beg & $1-m-n$ & ləmmən- & z-r & zor- \\
\hline
\end{tabular}

It has been observed that the two languages exhibit differences in the pattern employed in the derivation of verb stems. In both languages, the pattern to derive the tri-literal perfective stem is $\mathrm{CVC}_{1} \mathrm{C}_{1} \mathrm{VC}$-. In Argobba, however, the patterns $\mathrm{CVC}_{1} \mathrm{C}_{2^{-}}$and $\mathrm{C}_{1} \mathrm{VC}_{2} \mathrm{VC}_{3}$ also are observed which are not allowed in Amharic. Consider the examples in (31).

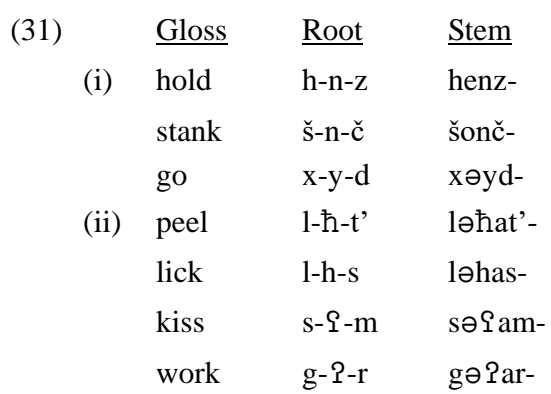

In the derivation of the perfective stem from quadriradical root, the second vowel is /ə/ in Amharic. In Argobba, it is consistently /a/ as shown in (32).

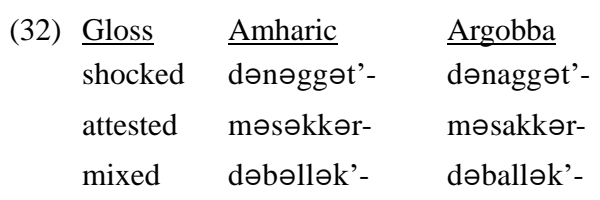




\section{Getahun Amare}

change mənəzzər- mənazzər-

In addition to the ones in (32), in Argobba, but not in Amharic, there is a pattern (C) $\mathrm{VC}_{1} \mathrm{C}_{2} \mathrm{VC}$ - to derive a perfective stem like ?as?am- 'sold' derived from the quadriradical root $P-s-P-m$.

In the derivation of the stem under consideration, íCCVC- is a common derivation pattern in Argobba as exemplified in (33), which is not the case in Amharic.

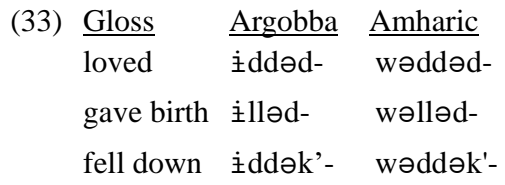

Another related matter with the perfective stem that is worth mentioning is the derivation of Type B verbs. In both languages, Type B verbs are characterized by geminating their penultimate radical in all their stems (perfective, imperfective gerundive etc.). Nevertheless, in Argobba, but not in Amharic, Type B verbs are characterized not only by geminating the penultimate radical but also by having the first vowel /e/. Consider the cognate stems in (34).

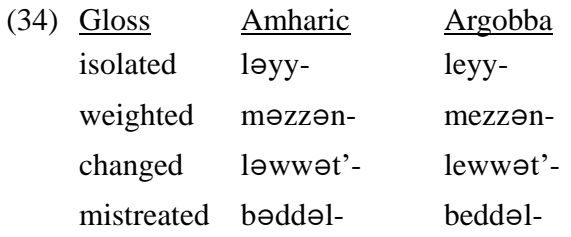

The other difference observed in the derivation of the verbal stems in the two languages is on the gerundive verbal stem derived from triradical root. In Amharic, the gerundive stem derived from triradical root follows the pattern $\mathrm{CVC}_{1} \mathrm{C}_{2^{-}}$, with the exception of the $1 \mathrm{~S}$ that has the stem $\mathrm{CVC}_{1} \dot{\text { 主 }} \mathrm{C}_{2} \mathrm{C}_{2^{-}}: s ə b$ 主 $r r$-e 'I having broken'. In Argobba, however, the derivation of the stem is characterized by geminating the ultimate radical following the pattern $\mathrm{CVC}_{\mathrm{i}} \mathrm{C}_{1} \mathrm{C}_{1^{-}}$. Compare the examples in (35) from Amharic and the ones in (36) from Argobba.

\begin{tabular}{|c|c|c|c|c|}
\hline \multirow[t]{5}{*}{ (35) } & $\underline{\text { Gloss }}$ & $\underline{\text { Root }}$ & $\underline{\text { Stem }}$ & \multirow{5}{*}{ (Amharic) } \\
\hline & break & s-b-r & səbr- & \\
\hline & whip & g-r-f & gərf- & \\
\hline & wear & 1-b-s & ləbs- & \\
\hline & insult & s-d-b & sədb- & \\
\hline \multirow[t]{4}{*}{ (36) } & $\underline{\text { Gloss }}$ & $\underline{\text { Root }}$ & $\underline{\text { Stem }}$ & \multirow{4}{*}{ (Argobba) } \\
\hline & break & s-b-r & səb主rr- & \\
\hline & wear & 1-w-s & 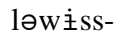 & \\
\hline & whip & $g-r-f$ & gərìff- & \\
\hline
\end{tabular}




\section{Argobba and Amharic: Putting a Stop to a Quandary}

insult s-d-w sədìww-

In Amharic, verbs which have lost their ultimate radical add /t/ in final position in the derivation of the gerundive stem as shown in (37).

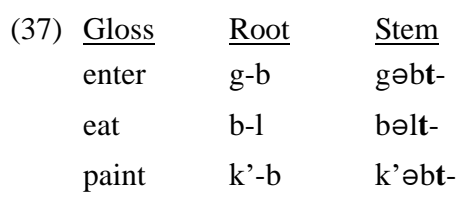

In Argobba, however, verbs which have lost either their ultimate or the penultimate radical (38i) and some verbs which have lost neither of their radicals (38ii) add /čč/ in the final position.

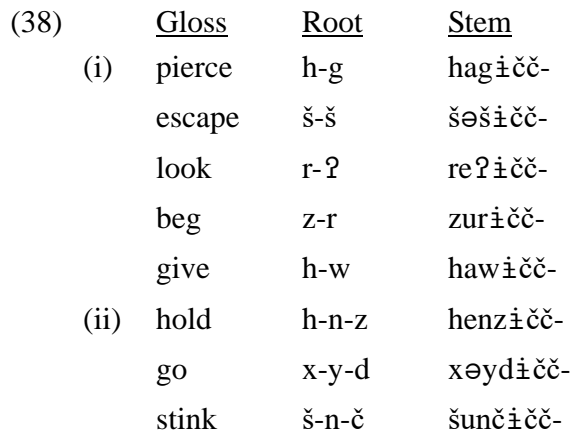

In the Argobba variety spoken in Gacheni and surrounding areas, the gerundive stem is derived by adding the voiced alveolar stop /d/ in stem final position as in $s \ni d b \dot{\text { i }} d$-from the s-d-b 'insult'.

In both languages, verbs are derived not only by non-concatenative means, but also by concatenative affixes like $a$-, $a s$ - and $t ə-$. The morpheme $a$ - and $a s$ - are used to derive a causative stem in both Amharic and Argobba. In Amharic, the causative morpheme a-, which is mainly attached to intransitive verbs, cannot be attached to verbs like wəddək''fell down'. As a result the derivation of $a$-wəddək'- is not possible in the language. In Argobba, however, $a-w ə d d ə k$ '- is possible for the meaning 'caused to fall', exactly like in Tigrinya (Getahun, 2009).

In the causative stem derivation with the causative morpheme as-, in Amharic, the first vowel of the base stem is not affected. In Argobba, in contrast, the first vowel becomes /e/ in the causative stem (Getahun, 2006). Consider the examples in (39) and in (40) from Amharic and Argobba respectively.
(39) Base Stem

$\begin{array}{ll}\text { gəddəl- } & \text { 'killed' } \\ \text { ləbbəs- } & \text { 'wore' }\end{array}$
Derived Stem
as-gəddəl- 'caused to kill'
nəkkəs-
as- ləbbəs-
as- nəkkəs-
'caused to wear'
'caused to bite' 


\section{Getahun Amare}

\begin{tabular}{|c|c|c|c|}
\hline (40) Base Stem & & Derived Sten & \\
\hline gəddəl- & 'killed' & as-geddəl- & 'caused to kill' \\
\hline ləwwəs- & 'wore' & as- lewwəs- & 'caused to wear' \\
\hline nəkkəs- & 'bit' & as- nekkəs- & 'caused to bite' \\
\hline
\end{tabular}

As can be observed from the examples in (40), the attachment of the causative morpheme as- affects only the first vowel of the base stem. It does not have any effect on the consonants or radicals of the base stem. However, Hudson (1997:479) writes" Causatives in Argobba are formed with the prefix $a$-, and geminating-type causatives with as-." The empirical facts from the language, however, do not substantiate Hudson's claim.

In Amharic as well as in Argobba, the passive verbal stem is derived with the passive morpheme $t \partial$ - prefixed to a transitive stem. The difference between the two languages is on the surface realization of the morpheme and the form of the passive stem. In Amharic, the passive morpheme appears as it stands as shown in (41).

\begin{tabular}{|c|c|c|c|}
\hline (41) Base Stem & & Derived Stem & \\
\hline gəddəl- & 'killed' & tə- gəddəl- & 'was killed' \\
\hline səbbər- & 'broke' & tə- səbbər- & 'was broken' \\
\hline gərrəf- & 'swept' & tə- gərrəf- & 'was swept' \\
\hline
\end{tabular}

In Argobba, however, the passive morpheme does not surface in the way that it does in Amharic. Rather, the /ə/ in $t \partial$ - is deleted and the / $t /$ assimilates to the first radical of the base stem and results in the gemination of the first radical provided that the first radical is not a guttural sound. When the base begins with a guttural sound or a vowel, the /t/ appears geminating itself. In this case, as the language does not allow consonant cluster in the initial position, the epenthetic vowel/i / is inserted initially. The derivation of the passive stems are, thus, exemplified in (42) with the passive morpheme in question.

\begin{tabular}{|c|c|c|c|}
\hline \multirow[t]{9}{*}{$(42)$} & $\underline{\text { Gloss }}$ & Base Stem & $\underline{\text { Derived Stem }}$ \\
\hline & insult & səddəw- & 主sseddəw- \\
\hline & kiss & sə९am- & 主sseiam- \\
\hline & wear & ləwwวs- & 主llewwəs- \\
\hline & wash & hat't'əw- & 主ttì het't'əw- \\
\hline & pierce & hagg- & $\dot{\dot{x}} \mathrm{tt} \dot{\mathrm{i} h e g g-}$ \\
\hline & tie & Passər- & 主tti王 Pessər- \\
\hline & farm & ћarrəs & 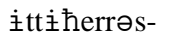 \\
\hline & tell & awid- & 主ttawid- \\
\hline
\end{tabular}

As can be observed from the above examples, in the derivation of the passive stems, the first vowel in the base stem becomes /e/ in the derived stem exactly like what we have seen in the causative derivation with the as- morpheme. With regard to the passive morpheme, one possible question that could be raised is that how one can know that the passive 


\section{Argobba and Amharic: Putting a Stop to a Quandary}

morpheme is $t \partial$ - in Argobba. The main reasons for assuming $t ə$ - as the passive morpheme are empirical and genetic. As to the first reason, the morpheme surfaces as it stands with the gerundive verb forms like in $t \curvearrowright$-het' ' $w w$-o 'it having been washed'. With regard to the second reason, the morpheme appears as $t ə-$ in genetically related languages like Harari, Kistanya and Tigrinya among others (Getahun, 2010).

\subsubsection{Subject and object agreement affixes}

In both languages, there are two sets of pronoun affixes attached to verbs or verbal stems: subject and object agreement affixes. The subject agreement pronouns are obligatory and can be a prefix or a suffix. The object pronouns, however, are consistently a suffix in both languages. In (43)-(45), we first see the subject pronoun affixes of both languages in different verbal stems.

In Amharic as well as in Argobba, the subject pronouns are suffixes in perfective and gerundive verbs, but prefixes in imperfective verbal stem. The following examples show the inflection of the cognate perfective (43), gerundive (44), and imperfective verbal stems (45) respectively, derived from the root $s-d-b / w$ 'insult' for subject.

(43)

\begin{tabular}{|c|c|c|}
\hline & $\underline{\text { Amharic }}$ & Argobba \\
\hline 1 & səddəb-ku & səddəw-eћu \\
\hline $2 \mathrm{M}$ & səddəb-k & səddəw-ex \\
\hline $\mathrm{F}$ & səddəb-š & səddəw-eš \\
\hline $3 \mathrm{M}$ & səddəb-ə & səddəw- $\varnothing /-\mathrm{a}$ \\
\hline $\mathrm{F}$ & səddəb-əčč & səddəw-əčč/ -əd \\
\hline 1 & səddəb-n & səddəw-əna \\
\hline 2 & səddəb-aččìhu & səddəw-eћum \\
\hline 3 & səddəb-u & səddəw-əy \\
\hline
\end{tabular}

As can be observed from the examples in (43), there are minor differences in 2M, 1PL and major differences in 1S, 3M, 2PL and 3PL subject pronoun suffixes.

(44)

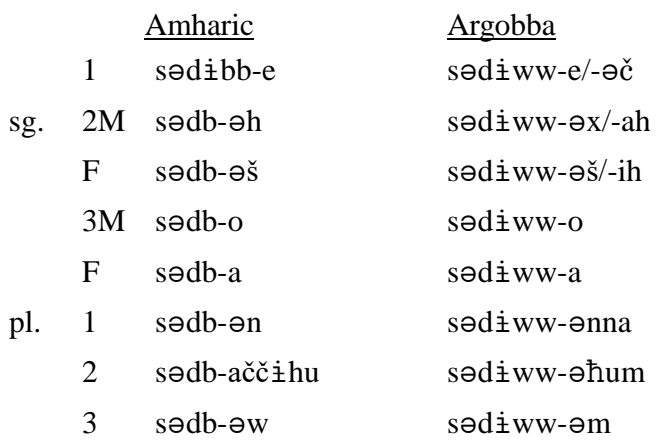

As is observed from the examples in (44), in addition to the difference in the stem formation, we observe a considerable difference in the 2PL and 3PL subject pronoun 


\section{Getahun Amare}

suffixes between the two languages.

(45)

\begin{tabular}{|c|c|c|}
\hline & Amharic & Argobba \\
\hline 1 & 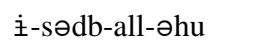 & sədw-ìll-əћu \\
\hline $2 \mathrm{M}$ & tì- sədb-all-əh & (tì)-sədw-ìll-ex \\
\hline $\mathrm{F}$ & tì- sədb-i-all-ə̌̌ & 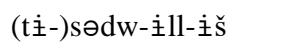 \\
\hline $3 \mathrm{M}$ & yì-sədb-all & (y主-)sədw-əl \\
\hline $\mathrm{F}$ & tì-sədb- all-əčč & 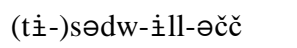 \\
\hline 1 & 主nn主-sədb-all-ən & 主nn主-sədw-ìnna \\
\hline 2 & tì-sədb-all-aččìhu & (tiz-)sədw-u-ìll-uhum \\
\hline 3 & yi̇-sədb-all-u & 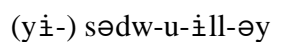 \\
\hline
\end{tabular}

In (45), in Argobba, but not in Amharic, there is no phonetically realized subject pronoun prefix for 1S. In the cases of the other persons, the subject pronoun prefixes are attached to the imperfective stem obligatorily in Amharic. In Argobba, in contrast, with the exception of the 1PL, the subject pronoun prefixes are not commonly attached to the imperfective verb stem. The subject can be identified from the subject pronoun suffix attached to the auxiliary. For instance, $s ə d w$-i̇ $l l-ə \check{c} \check{c}$ - $ə y$ 'She insults /will insult him' is more acceptable than $t \dot{i}-s \partial d w-\dot{z} l l-\partial \check{c} \check{c}-\partial y$. The use of the prefix subject pronoun, thus, seems to be the influence of Amharic. Besides, in Argobba, there is one peculiar property observed in 1PL: there is no auxiliary following the verb stem. As a result, the subject pronoun suffix, that is supposed to be attached to the auxiliary, is directly attached to the verb stem. In the 2PL and 3PL, the verb stems bear both the prefix and the suffix subject pronouns in addition to the subject pronoun on the auxiliary. In Amharic, with the exception of 2FS, the stems bear the prefix subject pronoun only. The suffix $-i$ that co-occur with the pronoun $t \dot{z}-$ for $2 \mathrm{FS}$ in Amharic is absent in Argobba. Furthermore, the present auxiliary is -all consistently in Amharic. It appears as -əl and - $l l$ - in Argobba.

In connection with the issue under consideration, the cognate past auxiliary verbs nəbbər 'was, were' in Amharic and immbər in Argobba co-occur with the gerundive and the imperfective verbs. The basic difference between the two languages is that the auxiliary in Argobba, with the exception of the $3 \mathrm{M}$, inflects for person, number and gender by attaching the subject pronoun suffixes used with the perfective verbal stem, but the one in Amharic does not. Let us see the gerundive verb in (44) with the respective auxiliary verbs in both languages in (46), for the meaning 'I was insulting', etc.

(46)

$$
\begin{aligned}
& \text { Amharic Argobba } \\
& 1 \text { sədílbb-e nəbbər sədìww-e immbər-eћu } \\
& \text { sg. } 2 \mathrm{M} \text { sədb-əh nəbbər sədìww-əx ìmbər-ex } \\
& \text { F sədb-əš nəbbər sədìww-əš } \\
& \text { 3M sədb-o nəbbər sədìww-o 主mbər- } \varnothing
\end{aligned}
$$


Argobba and Amharic: Putting a Stop to a Quandary

\begin{tabular}{|c|c|c|c|}
\hline \multirow{4}{*}{ pl. } & $\mathrm{F}$ & sədb-a nəbbər & sədìww-a i̇mbər-əčč \\
\hline & 1 & sədb-ən nəbbər & sədi்ww-ənna i̇mbər-ena \\
\hline & 2 & sədb-aččìhu nəbbər & sədìww-əћum ìmbər-eћum \\
\hline & 3 & sədb-əw nəbbər & sədìww-əm ìmbər-əy \\
\hline
\end{tabular}

Now, let us come back to the object pronoun suffixes. The object pronoun is suffixed to a verb following the subject pronoun suffix in perfective and gerundive verbs and to the verbal stem in the imperfective verb in both languages. Consider the following examples with the perfective verb səddəbəčč 'She insulted' and Pemmərəčč 'She ordered' in Amharic and Argobba respectively.

(47)

\begin{tabular}{|c|c|c|c|}
\hline \multirow{4}{*}{ sg. } & & Amharic & Argobba \\
\hline & 1 & səddəbəčč -ìn̆n̆ & Pemmərəčč -əňn̆ \\
\hline & $2 \mathrm{M}$ & səddəbəčč -ìh & Pemmərəčč - əx \\
\hline & $\mathrm{F}$ & səddəbəčč -i் $\check{s}$ & Pemmərəčč - əš \\
\hline \multirow{5}{*}{ pl. } & $3 \mathrm{M}$ & səddəbəčč - $-\dot{z} w$ & Pemmərəčč - əy-e \\
\hline & $\mathrm{F}$ & səddəbəčč -at & Pemmərəčč - әуа \\
\hline & 1 & səddəbəčč -ìn & Pemmərəčč - əna \\
\hline & 2 & səddəbəčč -aččìhu & Pemmərəčč - əћum \\
\hline & 3 & səddəbəčč - aččəw & Pemmərəčč - əyem \\
\hline
\end{tabular}

From the examples in (47), we observe that the two languages have considerable difference in the $3 \mathrm{M}, 3 \mathrm{~F}, 2 \mathrm{PL}$ and $3 \mathrm{PL}$ object pronouns.

The other significant difference observed between the two languages is in the use of the object pronoun suffixes with different verb forms. That is, in Amharic, the object pronoun suffixes identified in the perfective verb form are used irrespective of the verb form. In Argobba, however, some of the object pronoun suffixes differ in the imperfective and gerundive verbs from the ones we saw in the perfective verbs. The object pronoun suffixes $-ə y$, -əya and -əyem for $3 \mathrm{M}, 3 \mathrm{~F}$ and 3PL respectively in the perfective verb become - $ə b b$, $-\partial b b a$ and -əbbem respectively in the imperfective verbs.

The Argobba examples in (48) are illustrative examples with the verb $n ə k s$ ' $\mathrm{He} / \mathrm{It}$ bites /will bite'.

(48)

\begin{tabular}{|c|c|c|}
\hline & $\underline{\text { Singular }}$ & $\underline{\text { Plural }}$ \\
\hline 1 & nəks-əňn̆- əl & $\overline{\text { nəks-əna-həl }}$ \\
\hline $2 \mathrm{M}$ & nəks-əx- əl & \\
\hline $\mathrm{F}$ & nəks-əહ̌-ə & nəks-əћum-əl \\
\hline $3 \mathrm{M}$ & nəks-əbb- əl & \\
\hline $\mathrm{F}$ & nəks-əbba-hal & nəks-əbbem-ə \\
\hline
\end{tabular}

4.5.4 The progressive aspect 


\section{Getahun Amare}

Amharic and Argobba express the progressive aspect in remarkably different structures. In Amharic, the structure is formed by prefixing the progressive aspect morpheme $\dot{i} y y \theta-$ to a perfective verb form and combining auxiliary verbs. In Argobba, in contrast, the aspect in question is expressed in a structure composed of an infinitive verb and an auxiliary verb inflected for subject. Compare the examples in (49) below.

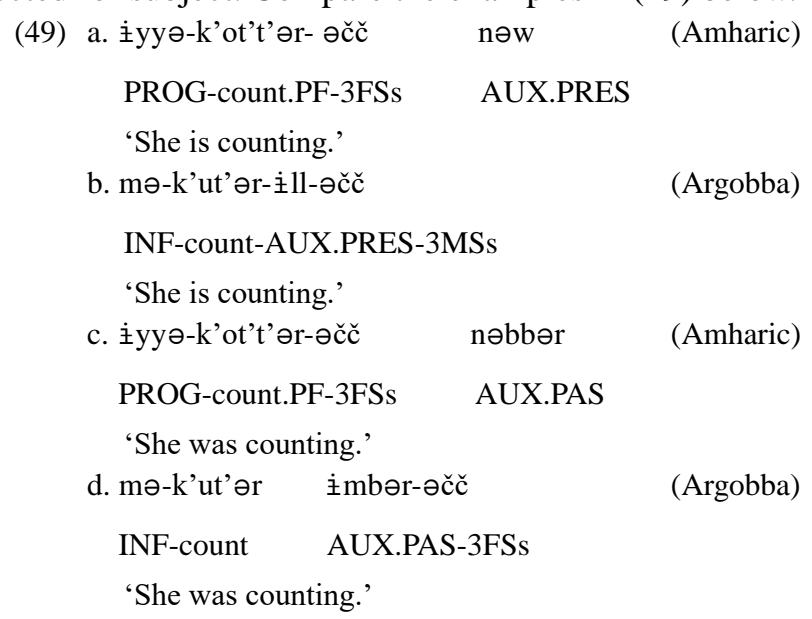

In Amharic, the relative morpheme is $y ə$ - which is prefixed to both perfective and imperfective verbs. In Argobba, however, the morpheme $i$ - and $m$ - are prefixed to perfective and imperfective verbs respectively (Getahun, 2008). Consider the following examples from both languages.

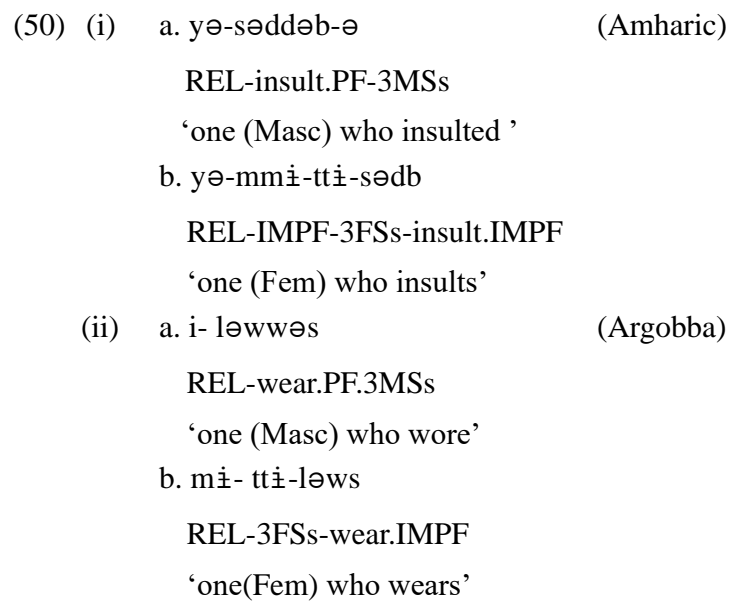

The data presented in (50) contradicts the claim made by Hudson (1997:482), that 'In Argobba the past tense verb of an adjective clause is prefixed by $y \ddot{a}$-. The non-past verb of an adjective clause is prefixed by yämm- or əmm-.' His claim works for Amharic, but not 
for Argobba.

Besides the differences in the relativizer morphemes, there are also other differences exhibited in the relative clause construction. In Amharic, the head of the relative phrase does not bear the definite article. In Argobba, on the contrary, singular head nouns obligatorily bear the definite suffix as illustrated in (51).

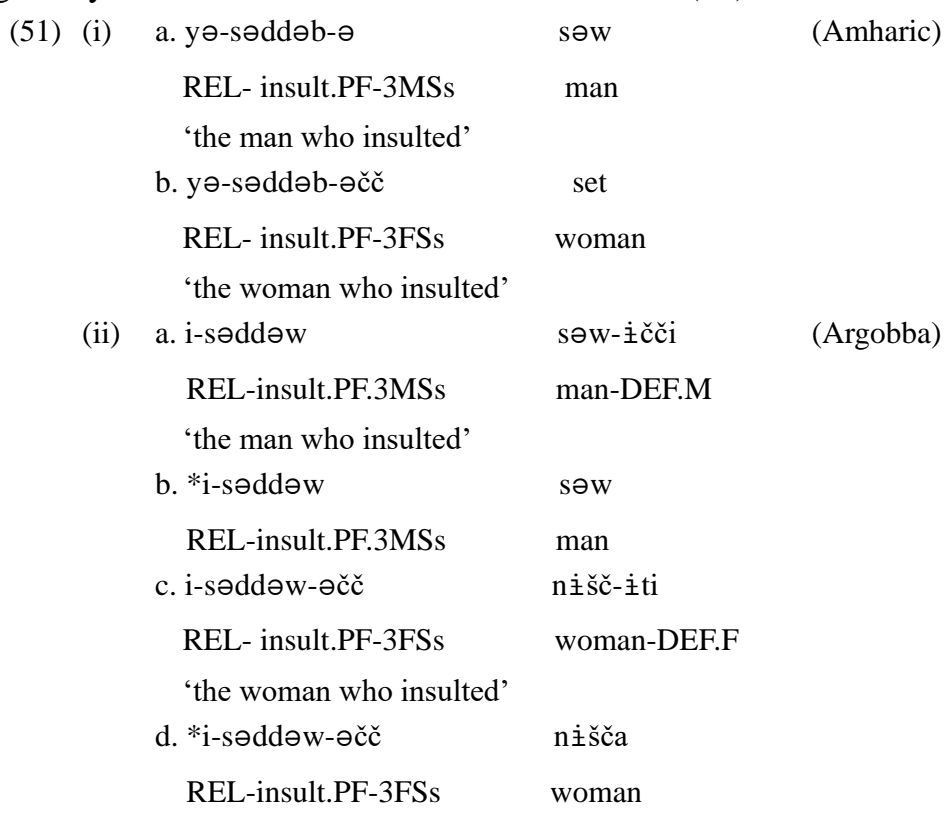

Another related point to be raised here is that if the relative phrase is used as the object of a transitive verb, the accusative case marker $-n$ is suffixed to the relative verb in Amharic. In Argobba, however, the case marker is suffixed to the head noun, not to the relative verb.

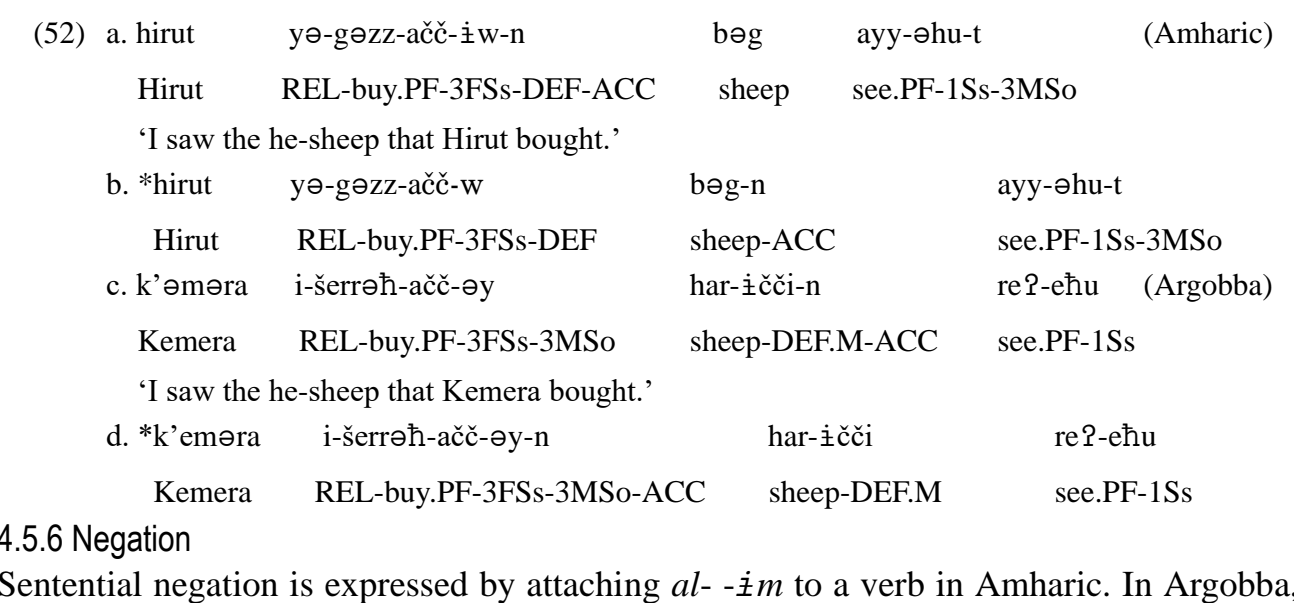




\section{Getahun Amare}

Leslau (1959:261) states that "The negative perfect is formed by the prefixed element of negative $a l$ - and by suffixed morpheme $-u$ or $-m$ in the plural forms ending in a vowel." Of course, the negative morpheme $-u$ is observed in the Argobba variety spoken in Gacheni and surrounding areas (Getahun, 2009). Besides, there is a difference between the two languages in the form of the prefix al-in negative perfective verbs. In Amharic, the negative prefix surfaces as it stands prefixed to the base verb form in question. In Argobba, however, the $/ 1 /$ in al-assimilates to the first radical of the base and results in gemination of the first radical provided that the first radical is not a guttural sound. Consider the examples in (53).

$$
\begin{aligned}
& \text { Amharic } \\
& \text { al- səddəb-əčč-ìm } \\
& \text { al- gəddəl-u- m } \\
& \text { al- mət't'a-hu- m }
\end{aligned}
$$

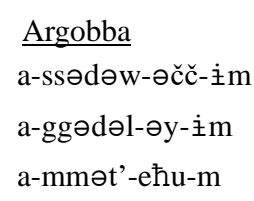

The other crucial difference observed from the examples in (53) is that in Amharic both the affirmative and the negative perfective verbs geminate the penultimate radical. On the contrary, in Argobba, the perfective negative verb does not geminate the penultimate radical. In this case, Argobba resembles the Gurage languages. For instance, in Kistanya, one of the Gurage languages, the affirmative form $s \partial d d \partial b$ - $\partial t$ 'She insulted' has the

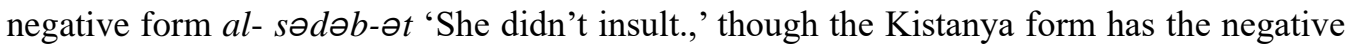
al- like Amharic.

In the imperfective negative form, in both languages, the $/ 1 /$ in al- assimilates to the subject pronoun prefixes. The difference between the two languages is on the $3 \mathrm{M}$ and $3 \mathrm{PL}$ that have the $y$ - pronoun prefix. In Amharic, /l/ does not assimilate to the prefix, but is elided. Thus, we have the negative forms $a-y$-səbr-im 'He does/will not break' and $a-y$ səbr-u-m 'They do/will not break' in Amharic. In Argobba, however, the prefix pronoun becomes / $i-/$ and the negative prefix disappears. Hence, the above cognate negative verbs in Amharic surface like $i-s ə b r-i m$ and $i-s ə b r-u-m$ for the same meaning, in Argobba.

In Amharic, in relative negative verb forms, the negative prefix immediately follows the relative prefix yə-in the perfective, and it follows the imperfective morpheme - $\mathrm{mm}$ - in imperfective negative relative verb forms. In Argobba, in contrast, the relative morphemes, $i$ - and $m$-, which are used with perfective and imperfective verb forms respectively, do not surface in the negative relative verb forms. Consider the examples in (54).
(54) (i)
a. anbəssa
yə- gəddəl-ə-w
səw
(Amharic)
lion
REL- kill.PF-3MSs-DEF
man
'the man who killed a lion'
b. anbəssa $\quad \mathrm{y}$ - al- gəddəl-ə-w
səw
lion
REL-NEG-kill.PF-3MSs-DEF
man 
Argobba and Amharic: Putting a Stop to a Quandary

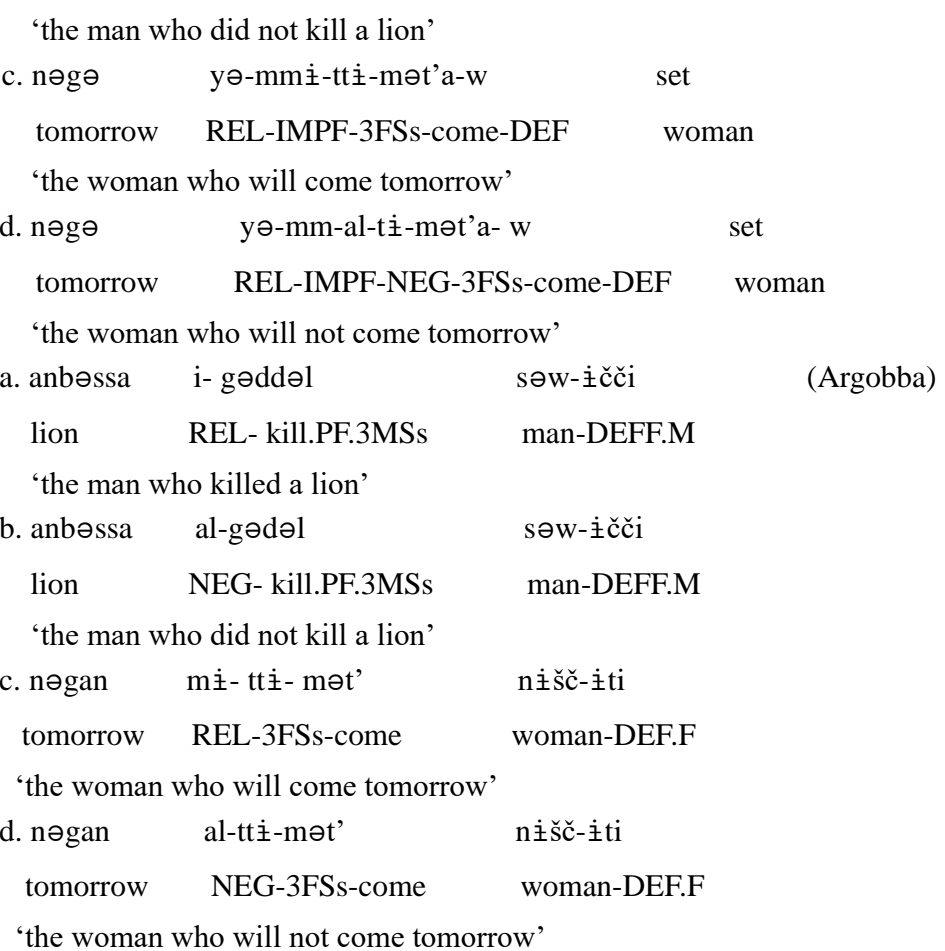

\subsection{Adpositions}

The two languages use some similar and some other completely different prepositions and postpositions as shown in (55).

\begin{tabular}{|c|c|c|c|}
\hline \multirow[t]{11}{*}{ (55) } & Amharic & $\underline{\text { Argobba }}$ & \\
\hline & bə- & bə- & 'with, by' \\
\hline & lə- & lə- & 'for' \\
\hline & $\dot{\dot{x}}-$ & tə- & 'in' \\
\hline & 主ndə & amə & 'like \\
\hline & kə- & 主ntə- & 'from' \\
\hline & $\dot{i}-\ldots$. lay & 主ntə-.....rašo & 'on, up on' \\
\hline & kə-... gar & $\mathrm{dul} / \mathrm{m} ə \mathrm{~s}$ & 'accompanying with' \\
\hline & wədə & bə-...ama/ məddi & 'to/ towards' \\
\hline & $\dot{\dot{x}}-\ldots w \dot{\mathrm{i}}$ st' & tə-...wəf̌̆'e & 'inside' \\
\hline & $\dot{z}-\ldots$ at' & tə-...gi & 'near, beside' \\
\hline
\end{tabular}

\section{Summary and conclusions}

Argobba and Amharic belong to the South Ethio-Semitic subfamily. In some previous studies, Argobba was treated as the dialect of Amharic. In this paper, the author argues not 


\section{Getahun Amare}

only against this presupposition but also to bring the issue at its closing stages, that is, to make a case that Amharic and Argobba are independent languages.

As members of the same subfamily, Argobba and Amharic have lexical items which are cognate with each other; and as different languages, they have different linguistic forms for the same meaning. Such differences are clearly observed in lexical and functional categories. Argobba and Amharic have some completely different and some related forms of independent and dependent personal pronouns.

Amharic and Argobba use different gender marked definite article suffixes. Furthermore, in Amharic, plural nouns take the definite article morpheme - $u$. In Argobba, in contrast, plural nouns are not morphologically marked for definiteness. In connection with this, in an NP structure headed by a definite noun, the definite article suffix appears on a modifier or quantifier, if any, in Amharic. In contrast, in Argobba, a definite article suffix consistently occurs on the head noun. In Amharic, both adjectives and nouns use the same form of definite article suffix. In contrast, the two categories (adjectives and nouns) use different definite articles in Argobba. In Argobba, but not in Amharic, a head noun modified by a relative clause, a genitive NP or a demonstrative obligatorily bears a definite article suffix. Argobba and Amharic use different forms of demonstratives which are marked for number and gender in Amharic, but only for number in Argobba. In Argobba, but not in Amharic, a demonstrative and a definite article co-occur in a single NP structure.

In Argobba, there are perfective stem derivation patterns like $\mathrm{CVC}_{1} \mathrm{C}_{2}, \mathrm{C}_{1} \mathrm{VC}_{2} \mathrm{VC}_{3}$, $\mathrm{CVC}_{1} \mathrm{C}_{2} \mathrm{VC}$ - and $\dot{\mathrm{i} C C V C}$-, which are not allowed in Amharic. In Argobba, but not in

Amharic, the gerundive stem derivation is characterized by geminating the ultimate radical. In passive and in causative stem derivations with the causative morpheme as-, the first vowel of the base stem becomes /e/ in the derived forms in Argobba, but not in Amharic.

Amharic uses one relativizer morpheme for perfective and imperfective verbs. In contrast, Argobba uses two relativizers for the two verb forms. The other remarkable difference observed between the verbs of the two languages is in the perfective negative stems. In Amharic, the perfective negative verb has a geminated penultimate radical like its perfective affirmative counterpart. In Argobba, unlike the perfective affirmative form, the perfective negative verb surfaces without geminating its penultimate radical. In the negative relative verb form, the relative morpheme does not appear in Argobba, but it does in Amharic. It seems that the negative and the relativizer morphemes cannot co-occur in Argobba.

In sum, undeniably, Amharic has significant influence on Argobba. Consequently, the author does claim that the similarity between Amharic and Argobba comes from two sources: genetic and dominance. As sister languages, the two languages share cognate lexical elements and other grammatical properties. Argobba, as a dying language giving 
way to Amharic, it is beyond doubt that Amharic has remarkable dominance over Argobba that results in a shift to Amharic. Because of the fact that Argobba is an endangered language, its lexical and grammatical elements are eroded in some places. However, in places like Shonke and Telha, the language retains most of its lexical and grammatical features which clearly show that Argobba is not merely a dialect of Amharic. Bearing in mind the unhealthy relationship of the two languages, one can say without a shred of doubt that Argobba and Amharic are distinct, but sister languages.

\section{References}

Ahmed, S. M. M. \& L. J. M. Meded (n.d). Amharic Language Teaching Material [M]. Bedir Printing Press. Batibo, H. M. 2005. Language Decline and Death in Africa: Causes, Consequences, and Challenges [M]. Clevedon: Multilingual Matters Ltd.

Bender, M. L. et al. (eds.). 1976. Language in Ethiopia [M]. London: Oxford University Press.

Bender, M. L. \& H. Fulas. 1978. Amharic Verb Morphology [M]. East Lansing: African Studies Center, Michigan State University.

Cohen, M. 1931. Etudis d'ethiopien meridional [M]. Paris: Librairie Orientaliste Paul Beuthnen. . 1939. Nouvelle etudesd' ethiopien meridionale [M]. Paris: Librairie Ancienne Honore.

Demeke, G. A. 2003. Argobba -Amharic Dictionary [M]. Addis Ababa: Argobba Development Association. 2009. The Origin of Amharic [M]. Addis Ababa: French Center for Ethiopian Studies.

Gabriel, S. 1992. A Survey on Language Death in Africa [A]. In M. Brenzinger (ed.). Language Death: Factual and Theoretical Explanations with Special Reference to East Africa [C]. Berlin: Mouton de Gruyter, 301-417.

Gebre, B. 1991. Argobba Phonology and Orthography. (Unpublished).

Getahun, A. 2006. Causative Constructions in Argobba [A]. In Vold Eva Thue et al. (ed.). New Voice in Linguistics [C]. Cambridge: Cambridge Scholars Publishing, 199-210.

. 2008. Relative Clause Constructions in Argobba [R]. A paper presented at the 16th International Conference of Ethiopian Studies, Trondheim.

2009. Argobba Verb Morphology and Syntax: A Documentation with HPSG Analytic Framework

[D]. Ph. D. dissertation, NTNU, Trondheim. 2010. Passive in Argobba [J]. Journal of Ethiopian Studies, 43: 1-29.

Gutt, E. A. 1997. The Silte Group (East Gurage) [A]. In Robert Hetzron (ed.). The Semitic Languages, Abingdon [C]. London: Routledge, 509-534.

Hetzron, R. 1972. Ethiopian Semitic: Studies in Classification [M]. Manchester: Manchester University Press.

Hudson, G. 1997. Amharic and Argobba. In Robert Hetzron (ed.). The Semitic Languages [C]. Abingdon, London: Routledge, 457-485.

2000. Ethiopian Semitic Overview [J]. Journal of Ethiopian Studies, 33(2): 75-86.

Kifleyesus, A. 2003. Argobba Ethnography [A]. In Siegbert Uhlig (ed.). Encyclopedia Aethiopica [C]. Vol.1 (A-C). Wiesbaden: Harrassowitz, 332-334.

Lefebvre, C. T. 1845. Voyage en Abyssinie excute pendant less annees 1839-1843 [M]. Paris: Arthus Bertrand, Vol. 3, 329, 405-409.

Leslau, W. 1949. Examen dusuppose Argobba de Steetzen et de Lefbvre [J]. Word, 5(1): 46-54. 1957. Arabic Loanwords in Argobba (South Ethiopic) [J]. Journal of the American Oriental Society, 77(1): 36-39.

1959. A preliminary Description of Argobba [J]. Annales d'ethiopie, 3: 251-273.

1960. Sketches in Ethiopic Classification [A]. In Problemi Attuali di Scienza e di Culura, Atti dell

Convergn Internazionale di Studi Ethiopici $[\mathrm{C}]$. Roma: Academia Nazionale dei Lincei. . 1966. Classification of the Semitic Languages of Ethiopia [A]. In Proceedings of the Third 


\section{Getahun Amare}

International Conference of Ethiopian Studies [C]. Addis Ababa: Haile Selassie I University, 5-22. . 1978. Argobba Vocabulary [M]. Instituto per L'orente VIA A. Caroncini,19.

1997. Ethiopic Document: Argobba Grammar and Dictionary [M]. Wiesbaden: Harrassowitz.

Mohamed, H. et al. 2006. Sociolinguistic survey among Ethnically Argobba Communities [J]. ELRC Working Papers, 2(4): 415-454.

Siebert, R. 1994. Sociolinguistic survey report of the Argobba language of Ethiopia [J]. S.L.L.E. Linguistic Report, 22.

Vater, J. S. 1816. Proben Deutscher Volks-Mundarten: Dr. Seetzen's Linguistischer Nachlass Und Andere Sprach-Forschungen Und Sammlungen Besonders Uber Ostindien [M]. Leipzing: Gerhard Fleischer.

Voigt, R. 2003. Argobba [A]. In S. Uhlig (ed.). Encyclopedia Aethiopica [C]. Vol.1 (A-C), Wiesbaden: Harrassowitz, 330-331

Wagner, E. 1997. Harari [A]. In Robert Hetzron (ed.). The Semitic Languages [C]. Abingdon: Routledge, 486-508.

Waldron, S. 1984. Argobba [A]. In Weeks Richard (ed.). Muslim Peoples: A World Ethnographie Survey [C]. Greenwood Press, 49-53.

Wetter, A. 2006. The Argobba of Tollaha - a comparative overview [A]. In S. Uhlig (ed.), Proceedings of $15^{\text {th }}$ International Conference of Ethiopian Studies [C]. Verlag: Harrassowitz Verlag, 899-907. 2010. Das Argobba [M]. Köln: Rüdiger Köppe Verlang.

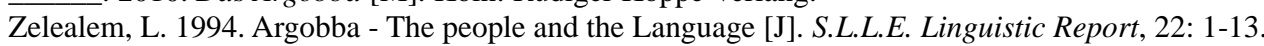

